\title{
VOLUME III NUMBER 3
}

SEPTEMBER 1970

\section{CENTRAL}
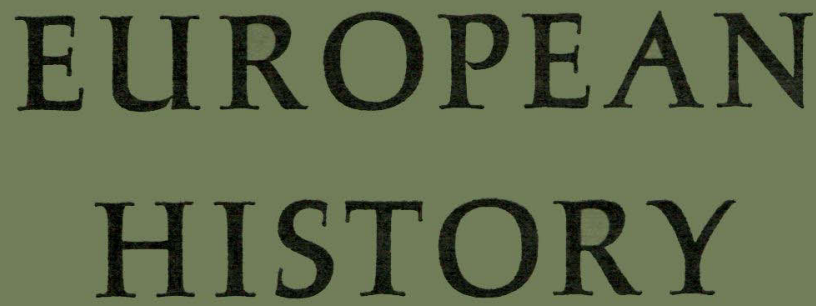

\section{Sponsored by the}

Conference Group for Central European History

of the American Historical Association

\author{
PUBLISHED QUARTERLY BY \\ EMORY UNIVERSITY
}


Because of difficulties which have now been overcome, publication of this issue of Central European History has been considerably delayed. Publication is now procecding at an accelerated pace, and will soon be back on schedule.

Central European History remains eager to consider any manuscript dealing with the history of German-speaking Central Europe, regardless of approach or time period. Such manuscripts should be sent to:

Central European History

Atlanta, Georgia 30322

\section{Walther Rathenau and the Weimar Republic}

\section{The Politics of Reparations}

DAVID FELIX Among the factors which led from the first to the second World War, the financial reparations Germany was forced to pay may have been the most crucial. Focusing on Walther Rathenau, German spokesman for fulfillment, this politicaleconomic study demonstrates how fulfillment was to have worked and how its failure led to World War II.

$\$ 9.00$

\section{German - Polish Relations, I9I8 - 1933}

HARALD VON RIEKHOFF Little study has been devoted to German-Polish relations of the interwar period, despite their importance to diplomatic relations among the other European states. Based on previously inaccessible source materials, this detailed examination of German-Polish diplomatic, economic, and military relations in the Weimar period is one of the most balanced and comprehensive ever published. \$15.00

\section{THE JOHNS HOPKINS PRESS}

Baltimore, Maryland 21218 


\section{CENTRAL EUROPEAN HISTORY}

\section{ARTICLES}

The Ruhrlade, Secret Cabinet of Heavy Industry

in the Weimar Republic

BY HENRY ASHBY TURNER, JR.

Austria and the Papal Election of 1823

BY ALAN J. REINERMAN

"Moro": The Resupply of German Submarines

in Spain, I939-1942

BY CHARLES B. BURDICK

\section{REVIEWS}

Dietrich Orlow, The History of the Nazi Party: 1919-1933

Akten zur deutschen auswärtigen Politik 1918-1945,

Series E: 1941-1945, Volume I

BY GEORGE O. KENT 


\section{CENTRAL E UROPEAN HIS TORY}

Sponsored by the Conference Group for Central European History of the American Historical Association

Published quarterly by Emory University, Atlanta, Georgia 30322

\section{BOARD OF EDITORS}

\author{
GORDON A. CRAIG \\ Stanford University \\ CARL J. FRIEDRICH \\ Harvard University \\ DIETRICH GERHARD \\ Washington University, St. Louis \\ ORON J. HALE \\ University of Virginia
}

\section{THEODORE S. HAMEROW \\ University of Wisconsin}

ROBERT A. KANN

Rutgers University

ENNO E. KRAEHE

University of Virginia

OTAKAR ODLOZILIK

University of Pennsylvania

HANS ROSENBERG

University of California, Berkeley

EDITOR

DOUGLAS A. UNFUG

Emory University

\section{ASSISTANT EDITOR \\ THEODOR V. BRODEK \\ Emory University}

All correspondence should be sent to Central European History, Emory University, Atlanta, Georgia 30322. \$ Subscription rate for U. S., possessions, and Canada: Individuals $\$ 8$ (U.S.) a year. Institutions: \$1 a year (3 years \$27). Single copies $\$ 2.75$. $\$$ Subscription rates for all other countries: Individuals $\$ 9$ a year. Institutions $\$ 11$ a year (3 years $\$ 30$ ). Single copies $\$ 3$. \Individual subscriptions include membership in the Conference Group for Central European History. All subscriptions postpaid. Checks should be made out to Central European History. $\$$ Second-class postage paid at Atlanta, Georgia, and at additional mailing offices. Published quarterly in March, June, September, and December.

Copyright $\odot$ 197I by Emory University. All rights reserved. $\$$ Printed by

The Stinehour Press, Lunenburg, Vermont. 